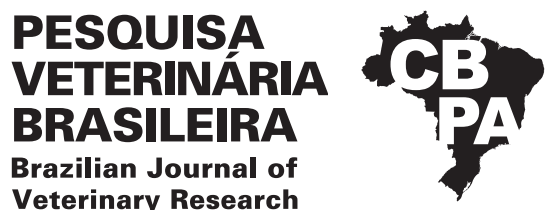

Pesq. Vet. Bras. 41:e06821, 2021

DOI: $10.1590 / 1678-5150-P V B-6821$

Original Article

Veterinarv Research

ISSN 0100-736X (Print)

Livestock Diseases

ISSN 1678-5150 (Online)

\title{
Susceptibility of field populations of Haematobia irritans to fipronil in Uruguay ${ }^{1}$
}

\author{
Cecilia Miraballes ${ }^{2}$, Antonio Thadeu M. Barros ${ }^{3}$, Martin Lucas², \\ Guilherme M. Klafke ${ }^{4}$, Luísa N. Domingues ${ }^{5}$ and Franklin Riet-Correa*2,6 (D)
}

\begin{abstract}
Miraballes C., Barros A.T.M., Lucas M., Klafke G.M., Domingues L.N \& Riet-Correa F. 2021. Susceptibility of field populations of Haematobia irritans to fipronil in Uruguay. Pesquisa Veterinária Brasileira 41:e06821, 2021. Instituto Nacional de Investigación Agropecuaria, Plataforma de Salud Animal, Estación Experimental INIA La Estanzuela, Ruta 50 Km 11, Colonia, 39173, Uruguay. E-mail: franklinrietcorrea@gmail.com

Fipronil was registered in Uruguay in 1997, and, since then, it has been used for the control of Haematobia irritans irritans and Rhipicephalus microplus. The susceptibility of $H$. irritants to this drug has not been evaluated. Therefore, the goal of the present study was to evaluate the resistance of $H$. irritans to fipronil. Additionally, a survey was carried out with the farmers to evaluate the use of fipronil for $H$. irritans control in the ranches where the flies came from. For the bioassays, 31 field populations of $H$. irritans were exposed to 10 concentrations of fipronil (3.2-16.0 $\left.\mathrm{gg} \cdot \mathrm{cm}^{2}\right)$, and their $\mathrm{LC}_{50}$ values were calculated using probit analysis. A bioassay was performed with horn flies from the susceptible colony maintained at the USDA-ARS Knipling-Bushland U.S. Livestock Insects Research Laboratory for comparison and calculation of resistance ratios (RRs). All 31 field populations surveyed in the study were susceptible to fipronil, with resistance ratios ranging from $<0.5$ to 2.2. Four populations with RRs $>1$ did not differ significantly from the susceptible strain. A single population showed an RR $>2.2$. Overall, the survey shows that fipronil was mostly used for R. microplus control, and in only three ranches, which were free of $R$. microplus, was fipronil used for horn fly control. Seventeen farmers did not use fipronil at all in the last three years. It is concluded that, in Uruguay, field populations of horn flies remain susceptible to fipronil.
\end{abstract}

INDEX TERMS: Fipronil, Uruguay, bioassays, Hematobia irritans, integrated pest management.

RESUMO.- [Suscetibilidade de populações de campo de Haematobia irritans ao fipronil no Uruguai.] O fipronil foi registrado no Uruguai em 1997 e, desde então, tem sido utilizado no controle de Haematobia irritans irritans e Rhipicephalus microplus. $\mathrm{O}$ objetivo do presente estudo foi avaliar a susceptibilidade de populações de campo de $H$. irritans ao fipronil. Além disso, foi realizada uma pesquisa

\footnotetext{
${ }^{1}$ Received on December 4, 2020.

Accepted for publication on December 16, 2020.

${ }^{2}$ Instituto Nacional de Investigación Agropecuaria (INIA), Plataforma de Salud Animal, Estación Experimental INIA Tacuarembó, Ruta $50 \mathrm{Km} \mathrm{11,} \mathrm{Colonia,}$ 39173, Uruguay. *Corresponding author: franklinrietcorrea@gmail.com

${ }^{3}$ Embrapa Beef Cattle, Campo Grande, MS, Brazil.

${ }^{4}$ Centro de Pesquisa em Saúde Animal, Instituto de Pesquisas Veterinárias Desidério Finamor, Estrada do Conde 6000, Sans Souci, Eldorado do Sul, RS 92990-000, Brazil.

${ }^{5}$ USDA-ARS Knipling-Bushland U.S. Livestock Insects Research Laboratory, 2700 Fredericksburg Road, Kerrville, TX, USA 78028.

${ }^{6}$ Graduate Program in Animal Science in the Tropics, Escola de Medicina Veterinária e Zootecnia, Universidade Federal da Bahia (UFBA), Av. Adhemar de Barros 500, Ondina, Salvador, BA 40170-110, Brazil.
}

para avaliar a utilização de fipronil e as práticas de controle de $H$. irritans nas fazendas de onde provinham as moscas. Para os bioensaios, 31 populações de campo de H. irritans foram

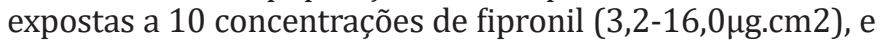
seus valores de CL50 foram calculados usando análise probit. Um bioensaio foi realizado com $H$. irritans da colônia suscetível mantida no USDA-ARS Knipling-Bushland U.S. Livestock Insects Research Laboratory para comparação e cálculo das razões de resistência (RRs). Todas as 31 populações de campo pesquisadas no estudo eram suscetíveis ao fipronil, com taxas de resistência variando de $<0,5$ à 2,2 . Quatro populações com Rrs $>1$ não diferiram significativamente da cepa suscetível. Uma única população apresentou RR $>2,2$. No geral, o fipronil tinha sido usado principalmente para o controle de $R$. microplus, e em apenas três fazendas, que estavam livres de R. microplus, o fipronil era utilizado para o controle da H. irritans. Em 17 fazendas não tinha sido utilizado fipronil nos últimos três anos. Conclui-se que no Uruguai as populações de H. irritans no campo permanecem suscetíveis ao fipronil.

TERMOS DE INDEXAÇÃO: Fipronil, Uruguai, bioensaios, controle integrado de pragas, Hematobia irritans. 


\section{INTRODUCTION}

The horn fly, Haematobia irritans Linnaeus, 1758 (Diptera: Muscidae), is one of the world's most important ectoparasites affecting livestock. Losses and control costs due to $H$. irritans were estimated in 730 million dollars in the USA (Foil \& Hogsette 1994) and 3.24 billon dollars in Brazil (Grisi et al. 2014). In Uruguay, reduction in weight gains caused by the horn fly has not been proved as the number of flies in cattle rarely exceeds 200, which is considered the threshold for treatment (Castro 2003). However, some farmers continue to treat livestock repeatedly, regardless of the recommended economic threshold. In Uruguay, H. irritans irritans has a bimodal population curve, with the first peak during spring (October to December), and a second peak at the end of the summer and the beginning of autumn, February to April (Castro et al. 2008). In the world, chemicals are widely used for controlling this fly, but resistance, especially against pyrethroids and organophosphates, has been a limiting factor (Oyarzún et al. 2008). In Uruguay, resistance to synthetic pyrethroids was detected five years after the horn fly entered the country and currently it widely spread in the horn fly population (Carballo \& Martínez 1991, Márquez et al. 1997).

Fipronil, a phenylpirazole insecticide, was registered in Uruguay in 1997. Since then, it has been used for the control of both H. irritans and Rhipicephalus microplus (Acari: Ixodidae). In R. microplus, resistance to fipronil was reported eight years after its registration (Cuore et al. 2007), and by 2016, 48\% of the analyzed populations were resistant (Cuore et al. 2017). Nevertheless, the susceptibility of $H$. irritans to fipronil has not been evaluated. As an integrated control strategy, Nari et al. (2013) suggested that fipronil should be used during the second generation of $R$. microplus to simultaneously reduce horn fly infestations.

It has become necessary to determine whether this active ingredient continues to be effective for the treatment of horn flies after 22 years of use. The objective of this study was to assess the susceptibility of field populations of $H$. irritans to fipronil in Uruguay.

\section{MATERIALS AND METHODS}

Bioassays. The susceptibility of Haematobia irritans to fipronil was assessed using the impregnated filter paper method (Sheppard \& Hinkle 1987). Insecticide kits were produced at Embrapa Beef Cattle (Campo Grande, Brazil) by diluting technical grade fipronil (PESTANAL ${ }^{\circledR}, 98.76 \%$ purity) in acetone (MERCK ${ }^{\circledR}$, analytical standard). Each kit contained three replicates of ten concentrations

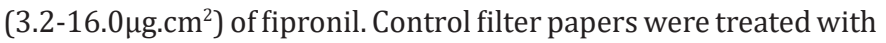
acetone only. The impregnated filter papers were packed in aluminum foil and kept under refrigeration until use, when they were placed in disposable plastic Petri dishes $(90 \mathrm{~mm}$ in diameter).

The bioassays of the field populations were performed from December 2018 to April 2019 with 31 field strains from different locations collected at a slaughterhouse located in Tacuarembó. Horn flies were collected directly from bovines with a sweep net before the animals were unloaded from trucks and tested within 10 to 20 min of capture, with an average of 25 flies for each petri dish. Fly mortality was determined after a $2 \mathrm{~h}$ exposure period, and flies that were unable to walk were considered dead.

To avoid mixtures of flies with different resistance profiles, flies were collected, immediately after the arrive to the slaughterhouse, only in trucks transporting cattle from a single ranch and from bovines with more than 100 flies. This sampling method allowed the collection of horn flies from eight of the 11 departments of Uruguay in which Rhipicephalus microplus is endemic.

In Uruguay, the treatment of cattle with insecticide or acaricide products prior to shipment for slaughter is not allowed. The withdrawal period before shipment for slaughter varies between the different active ingredients: the fipronil, ivermectin and ethion withdrawal periods are 100, 122 and 130 days, respectively. Pyrethroids are not frequently used because of the widespread resistance of horn flies to this compound, and none of the herds had bovines with ear tags impregnated with diazinon. Therefore, the horn flies were collected from bovines that had not received any treatment for at least 100 days.

A bioassay was performed with horn flies from the susceptible colony maintained at the USDA-ARS Knipling-Bushland U.S. Livestock Insects Research Laboratory (Kerrville, TX). The susceptible flies were exposed to nine concentrations of fipronil ranging from 0.2 to $9.6 \mu \mathrm{g} /$ $\mathrm{cm}^{2}$ plus one control (acetone only). Three replicates were used per concentration and an average of 25 flies was included in each replicate.

Management practices. A telephone survey of the ranchers in the locations where the horn flies originated was performed to assess the occurrence of $R$. microplus and control and preventive practices for cattle ticks and horn flies. Eleven closed multiplechoice questions were included in the survey: 1) ranch location, 2) occurrence of cattle ticks, 3) number of treatments for tick control per year, 4) fipronil use for tick control, 5) introduction of cattle to the farm by purchase, 6) frequency of cattle introduction, 7) preincome treatments, 8) preincome fipronil treatments, 9) horn fly treatments, 10) fipronil use for horn fly control, and 11) yearly number of treatments for horn fly control.

Statistical analysis. Probit analysis of the dosage-response data and $\mathrm{LC}_{50}$ values was performed using PoloPlus Software (Version 2.0, LeOra Software, Petaluma, California, USA). The differences between the $\mathrm{LC}_{50}$ from the field populations and the susceptible strain were considered significant when their $95 \%$ fiducial limits did not overlap (Barros et al. 2012). The resistance ratios (RRs) were calculated by dividing the $\mathrm{LC}_{50}$ from the field population by the $\mathrm{LC}_{50}$ from the susceptible strain.

Survey data were imported into STATA (Statacorp 2019) for descriptive analysis.

\section{RESULTS}

Most (80.6\%) wild horn fly populations showed a high susceptibility to fipronil, with $\mathrm{LC}_{50}$ values below those of the susceptible reference strain and RRs varying from 0.5 to 1 (Table 1). Additionally, four populations with RRs $>1$ did not differ significantly from the susceptible strain. A single population showed an $\mathrm{RR}>2.2\left(\mathrm{LC}_{50}>16.0\right)$ and $41.4 \%$ mortality in the highest concentration used in the bioassay; however, the analysis of the data was inconclusive because of the lack of an actual $\mathrm{LC}_{50}$ value and fiducial limit (Table 1).

Approximately $58 \%$ of the ranchers treat their cattle against horn flies, two-thirds of which also treat against Rhipicephalus microplus (Table 2). Of the six ranchers who reported the presence of R. microplus in their ranch and performed more than three treatments per year, only one mentioned the use of a specific treatment against horn flies (Table 2).

In the 31 surveyed ranches, fipronil was most used for tick control (Table 2). Fipronil was used only for horn fly control in three ranches, which were free of $R$. microplus. Sixteen ranchers did not use fipronil at all in the last 3 years (Table 2). 


\section{DISCUSSION AND CONCLUSION}

This study demonstrates the current status of the susceptibility of wild horn fly populations to fipronil in Uruguay. Monitoring the susceptibility of field populations through bioassays allows quick actions to be taken if resistance is detected. Concomitant surveying on parasite control practices routinely in use allows the proposition of appropriate recommendations in case problems are detected.

Fipronil was approved in Uruguay in 1997 (Cuore et al. 2007). To date, there have been no reports of resistance to this insecticide in field populations of Haematobia irritans, and the results of the present study confirmed the lack of resistance in the surveyed populations. In addition, our results suggest that the use of fipronil for horn fly control is being relatively well managed in the country, since horn fly treatments with this active ingredient were not frequent and were mainly framed within tick control plans.

When the horn fly entered Uruguay from Brazil, it still showed a high susceptibility to pyrethroid and organophosphate insecticides (Barros et al. 2012); however, resistance to pyrethroids was later reported (Márquez et al. 1997, Guglielmone et al. 2001) as a result of excessive treatment using this insecticide (Carballo 2004). Otherwise, there is still no suspicion of resistance to organophosphate in Uruguay.

Currently, a specific treatment against horn flies on farms where livestock is infested by cattle ticks is not recommended (Miraballes et al. 2018). When generational treatments for $R$. microplus are in place (Cuore et al. 2015), it is not necessary to overlap treatments targeting horn flies; furthermore, control of the second generation of R. microplus (two treatments are recommended) coincides with the strategic control of $H$. irritans, so control efforts can be optimized and the same insecticide can be used (Nari et al. 2013). For livestock producers that are free of cattle ticks, the treatment of bulls (Miraballes et al. 2018) or of bulls and $10 \%$ of the most infested cows may be used (Miraballes et al. 2019), and for dairy farmers, walkthrough traps may be a good choice (Miraballes et al. 2017).

Considering the importance of ectoparasite control and the risk of pesticide residues in meat for exportation, a program

Table 1. Susceptibility of horn fly populations to fipronil in Uruguay from December 2018 to April 2019

\begin{tabular}{|c|c|c|c|c|}
\hline \multirow{2}{*}{ Ranch } & \multirow{2}{*}{$\begin{array}{c}\mathrm{LC}_{50} \\
\left(\mu \mathrm{g} / \mathrm{cm}^{2}\right)\end{array}$} & \multicolumn{2}{|c|}{ Fiducial limits (95\%) } & \multirow{2}{*}{ Resistance ratio } \\
\hline & & Lower & Upper & \\
\hline 1 & 4.03 & 3.99 & 4.18 & 0.6 \\
\hline 2 & 5.18 & 4.71 & 5.66 & 0.7 \\
\hline 3 & 5.11 & 3.76 & 5.86 & 0.7 \\
\hline 4 & 5.35 & 4.31 & 6.18 & 0.7 \\
\hline 5 & $<5.60$ & - & - & $<0.8$ \\
\hline 6 & 9.38 & 8.57 & 10.23 & 1.3 \\
\hline 7 & 5.67 & 5.16 & 6.20 & 0.8 \\
\hline 8 & $<4.80$ & - & - & $<0.7$ \\
\hline 9 & 4.54 & 4.41 & 4.68 & 0.6 \\
\hline 10 & 4.37 & 3.56 & 4.85 & 0.6 \\
\hline 11 & 6.58 & 5.95 & 7.39 & 0.9 \\
\hline 12 & $<6.40$ & - & - & $<0.9$ \\
\hline 13 & 8.22 & 6.45 & 9.04 & 1.1 \\
\hline 14 & $<6.40$ & - & - & $<0.9$ \\
\hline 15 & $>16.0$ & - & - & $>2.2$ \\
\hline 16 & 5.56 & 4.80 & 6.09 & 0.8 \\
\hline 17 & 4.20 & 4.06 & 4.32 & 0.6 \\
\hline 18 & 5.58 & 4.33 & 7.09 & 0.8 \\
\hline 19 & $<8.00$ & - & - & $<1.1$ \\
\hline 20 & 6.84 & 5.43 & 8.98 & 0.9 \\
\hline 21 & 7.85 & 6.19 & 9.64 & 1.1 \\
\hline 22 & 6.68 & 6.01 & 7.61 & 0.9 \\
\hline 23 & 8.69 & 7.61 & 10.26 & 1.2 \\
\hline 24 & $<6.40$ & - & - & $<0.9$ \\
\hline 25 & $<4.00$ & - & - & $<0.5$ \\
\hline 26 & 4.43 & 3.56 & 5.05 & 0.6 \\
\hline 27 & 3.38 & 2.34 & 3.90 & 0.5 \\
\hline 28 & 4.74 & 4.36 & 5.10 & 0.7 \\
\hline 29 & 7. 04 & 6.73 & 7.32 & 1.0 \\
\hline 30 & 3.59 & 3.43 & 3.73 & 0.5 \\
\hline 31 & 3.73 & 3.17 & 4.13 & 0.5 \\
\hline Susceptible strain* & 7.28 & 4.67 & 14.88 & - \\
\hline
\end{tabular}

* USDA-ARS Knipling-Bushland U.S. Livestock Insects Research Laboratory. 
Table 2. Results of a survey to evaluate the managements practices and the use of fipronil for cattle tick and horn fly control in $\mathbf{3 1}$ farms from northeast Uruguay

\begin{tabular}{|c|c|c|c|c|c|c|c|c|c|c|c|}
\hline \multirow{3}{*}{ Farm } & \multirow{3}{*}{ Location } & \multirow{3}{*}{$\mathrm{RR}$} & \multicolumn{9}{|c|}{ Use of fipronil or other insecticides for } \\
\hline & & & \multicolumn{3}{|c|}{ Control of Rhipicephalus microplus } & \multicolumn{3}{|c|}{ Control of cattle purchased } & \multicolumn{3}{|c|}{ Control of Haematobia irritans } \\
\hline & & & Infestation & $\begin{array}{c}\text { Treatment/ } \\
\text { year }\end{array}$ & Fipronil use & $\begin{array}{c}\text { Cattle } \\
\text { purchase }\end{array}$ & Frequency & $\begin{array}{c}\text { Fipronil } \\
\text { pre-income }\end{array}$ & Treatment & $\begin{array}{c}\text { Treatment/ } \\
\text { year }\end{array}$ & Fipronil use \\
\hline 1 & Tacuarembo & 0.55 & Had & 1 to 3 & No & No & None & - & Yes & 1 to 3 & No \\
\hline 2 & Tacuarembo & 0.71 & Never had & 1 to 3 & No & Yes & Yearly & No & Yes & 4 to 6 & Yes \\
\hline 3 & Paysandu & 0.70 & Never had & 1 to 3 & No & Yes & Yearly & No & No & 0 & No \\
\hline 4 & Tacuarembo & 0.73 & Have & 7 to 9 & Yes & No & None & - & No & 0 & No \\
\hline 5 & Paysandu & - & Had & 0 & No & Yes & Yearly & Yes & Yes & 1 to 3 & No \\
\hline 7 & Paysandu & 1.28 & Never had & 0 & No & No & None & - & No & 0 & No \\
\hline 8 & Tacuarembo & 0.78 & Have & 4 to 6 & No & Yes & Monthly & No & No & 0 & No \\
\hline 9 & Rivera & - & Never had & 1 to 3 & No & Yes & Yearly & No & No & 0 & No \\
\hline 10 & Durazno & 0.62 & Never had & 0 & No & Yes & Monthly & No & Yes & 1 to 3 & Yes \\
\hline 11 & Rio Negro & 0.60 & Never had & 1 to 3 & No & Yes & Yearly & No & Yes & 1 to 3 & No \\
\hline 12 & Tacuarembó & 0.90 & Never had & 0 & No & Yes & Monthly & No & Yes & 1 to 3 & No \\
\hline 13 & Cerro Largo & - & Never had & 0 & No & Yes & Yearly & No & Yes & 1 to 3 & No \\
\hline 14 & Tacuarembó & 1.13 & Had & 1 to 3 & No & Yes & Monthly & No & Yes & 1 to 3 & Yes \\
\hline 15 & Rivera & - & Had & 1 to 3 & Yes & Yes & Monthly & No & Yes & 1 to 3 & No \\
\hline 16 & Tacuarembó & - & Never had & 1 to 3 & No & Yes & Monthly & No & Yes & 1 to 3 & No \\
\hline 17 & Tacuarembó & 0.76 & Never had & 0 & No & Yes & Monthly & No & No & 0 & No \\
\hline 18 & Cerro Largo & 0.58 & Never had & 0 & No & No & None & - & No & 0 & No \\
\hline 19 & Treinta y Tres & 0.76 & Have & 1 to 3 & Yes & Yes & Yearly & Yes & Yes & 1 to 3 & No \\
\hline 20 & Rivera & - & Have & 1 to 3 & Yes & Yes & Yearly & No & No & 0 & No \\
\hline 21 & Tacuarembó & 0.94 & Have & 1 to 3 & Yes & Yes & Yearly & No & Yes & 1 to 3 & No \\
\hline 22 & Rivera & 1.07 & Never had & 0 & No & No & None & No & Yes & 1 to 3 & No \\
\hline 23 & Cerro Largo & 0.92 & Have & 4 to 6 & No & Yes & Yearly & No & No & 0 & No \\
\hline 24 & Rivera & 1.19 & Have & 7 to 9 & No & Yes & Monthly & No & No & 0 & No \\
\hline 25 & Treinta y Tres & - & Never had & 0 & No & No & None & - & No & 0 & No \\
\hline 26 & Tacuarembó & - & Never had & 0 & No & No & None & - & Yes & 1 to 3 & No \\
\hline 27 & Tacuarembó & 0.60 & Never had & 1 to 3 & Yes & Yes & Monthly & Yes & Yes & 1 to 3 & No \\
\hline 28 & Paysandu & 0.46 & Have & 1 to 3 & Yes & Yes & Monthly & Yes & Yes & 1 to 3 & No \\
\hline 29 & Salto & 0.65 & Have & 7 to 9 & Yes & No & None & - & No & 0 & No \\
\hline 30 & Rivera & 0.97 & Have & 7 to 9 & Yes & No & None & No & Yes & 1 to 3 & No \\
\hline 31 & Tacuarembó & 0.49 & Had & 1 to 3 & No & Yes & Yearly & No & No & 0 & No \\
\hline 32 & Tacuarembó & 0.51 & Never had & 1 to 3 & No & No & None & - & Yes & 1 to 3 & No \\
\hline
\end{tabular}

for an integrated control strategy and monitoring ectoparasite susceptibility to insecticides is recommended in Uruguay.

Acknowledgments.- We would like to acknowledge Gonzalo Escayola, the ranchers, the staff of the slaughterhouse and the interns who collaborated on this study. This work was supported by the "Instituto Nacional de Investigación Agropecuaria” (INIA), Uruguay, project number CL 35.

Conflict of interest statement.- The authors declare no conflicts of interest.

\section{REFERENCES}

Barros A.T.M., Saueressig T.M., Gomes A., Koller W.W., Furlong J., Girão E.S. \& Oliveira A.A.D. 2012. Susceptibility of the horn fly, Haematobia irritans irritans (Diptera: Muscidae), to insecticides in Brazil. Revta Bras. Parasitol. Vet. 21(2):125-132.<https://dx.doi.org/10.1590/S1984-29612012000200010>

Carballo M. \& Martínez M. 1991. Hallazgo de Haematobia irritans en Uruguay. Veterinaria, Uruguay, 27(112):20-21.
Carballo M. 2004. Evaluación económica de la infestación por Haematobia irritans irritans (L) (Diptera:Muscidae) y sus métodos de control en Uruguay. Final Report, Project INIA/BID, LIA 027, Uruguay. 53p.

Castro E. 2003. Mosca de los cuernos: efecto en ganado de carne en Uruguay. Revta Plan Agropecuario 108:46-48.

Castro E., Gil A., Piaggio J., Chifflet L., Farias N.A., Solari M.A. \& Moon R.D. 2008. Population dynamics of horn fly, Haematobia irritans irritans (L.) (Diptera: muscidae), on Hereford cattle in Uruguay. Vet. Parasitol. 151(2/4):286-299. <https://dx.doi.org/10.1016/j.vetpar.2007.10.020 > <Mid:18093739>

Cuore U., Acosta W., Bermúdez F., Silva O.D., García I., Pérez R. \& Solari M.A. 2015. Tick generational treatment. Implementation of a methodology to eradicate Rhipicephalus (Boophilus) microplus tick resistant to macrocyclic lactones in a population management. Veterinaria, Uruguay, 51(198):14-25.

Cuore U., Solari M.A. \& Trelles A. 2017. Situación de la resistencia y primer diagnóstico de poblaciones de garrapatas Rhipicephalus (Boophilus) microplus resistente a cinco principios activos en forma simultánea en Uruguay. Veterinaria, Uruguay, 53(203):13-19. 
Cuore U., Trelles A., Sanchís J., Gayo V. \& Solari M.A. 2007. Primer diagnóstico de resistencia al Fipronil en la garrapata común del ganado Boophilus microplus. Veterinaria, Uruguay, 42(165/199):35-41.

Foil L.D. \& Hogsette J.A. 1994. Biology and control of tabanids, stable flies and horn flies. Rev. Sci. Tech. Off. Int. Epi. 13(4):1125-1158. <https://dx.doi.org/10.20506/rst.13.4.821><PMid:7711307>

Grisi L., Leite R.C., Martins J.R.D.S., Barros A.T.M.D., Andreotti R., Cançado P.H.D. \& Villela H.S. 2014. Reassessment of the potential economic impact of cattle parasites in Brazil. Revta Bras. Parasitol. Vet. 23(2):150-156. <https://dx.doi.org/10.1590/S1984-29612014042>

Guglielmone A.A., Castelli M.E., Volpogni M.M., Medus P.D., Martins J.R., Suárez V.H. \& Mangold A.J. 2001. Toxicity of cypermethrin and diazinon to Haematobia irritans (Diptera: Muscidae) in its American southern range. Vet. Parasitol. 101(1):67-73.<https://dx.doi.org/10.1016/s03044017(01)00490-3><PMid:11587834>

Márquez L., Moon R., Cardozo H., Cuore U., Trelles A. \& Bordaberry S. 1997. Primer diagnóstico de resistencia de Haematobia irritans (Diptera: Muscidae) en Uruguay. Determinación de susceptibilidad a cypermetrina y diazinón. Veterinaria, Uruguay, 33(133):20-23.

Miraballes C., Buscio D., Diaz A., Sanchez J., Riet-Correa F., Saravia A. \& CastroJaner E. 2017. Efficiency of a walk-through fly trap for Haematobia irritans control in milking cows in Uruguay. Vet. Parasitol., Reg. Stud. Rep. 10:126131. <https://dx.doi.org/10.1016/j.vprsr.2017.10.002><PMid:31014583>

Miraballes C., Sanchez J., Barros A.T.M., Hitateguy S., Moreno P., Saporiti T. \& Riet-Correa F. 2018. Influence of selective treatment of bulls on the infestation of Haematobia irritans on untreated cows. Vet. Parasitol. 260:58-62. <https://dx.doi.org/10.1016/j.vetpar.2018.08.012> <PMid:30197016>

Miraballes C., Stryhn H., Barros A.T.M., Lucas M., Domingues L.N., Ribeiro R. \& Riet-Correa F. 2019. Influence of selective treatment on Haematobia irritans infestation of untreated cattle. bioRxiv 798231. <https://dx.doi. org/10.1101/798231>

Nari A., Solari M.A., Cuore U., Lima A.L., Casaretto A. \& Valledor M.S. 2013 Control integrado de parásitos en establecimientos comerciales del Uruguay, p.589-604. In: Fiel C. \& Nari A. (Eds), Enfermedades Parasitarias de Importancia Clínica y Productiva en Rumiantes. Editorial Peri, Montevideo.

Oyarzún M.P., Quiroz A. \& Birkett M.A. 2008. Insecticide resistance in the horn fly: alternative control strategies. Med. Vet. Entomol. 22(3):188-202 <https://dx.doi.org/10.1111/j.1365-2915.2008.00733.x><PMid:18816268>

Sheppard D.C. \& Hinkle N.C. 1987. A field procedure using disposable materials to evaluate horn fly insecticide resistance. J. Agric. Entomol. 4(1):87-89.

Statacorp 2019. Statistical Software. College Station, StataCorp LP, USA. 